\title{
CHINA'S ECONOMIC POLICY TO NIGERIA IN OIL AFFAIRS
}

\author{
Anton Minardi ${ }^{1, a,{ }^{*}}$ and Riani Fauziah Lestari ${ }^{2, b}$ \\ ${ }^{1}$ International Relations Department Pasundan University Bandung, Indonesia \\ ${ }^{2}$ International Relations Department Pasundan University Bandung, Indonesia \\ aabdurrahmananton1975gmail.com, brianilestaril8@gmail.com \\ *Corresponding author
}

Cite as: MINARDI, A, LESTARI, F.R. (2019). China's economic policy to Nigeria in oil affairs, Ekonomicko-manazerske spektrum, 13(2), 28-36.

Available at: dx.doi.org/10.26552/ems.2019.2.28-36

\begin{abstract}
China was born as a new economic power, needs a lot of oil energy to support economic growth. But the high amount of oil consumption is not supported by the limited amount of oil. To fill the needs for energy oil China conducts its economic management to oil-producing countries. Africa has countries that save a lot of natural resources, especially oil, which is one of China's destinations to explore for its oil resources. One of the countries that has oil wealth is Nigeria. Research Method is descriptive analysis that draw the efforts made by China to launch its economic diplomacy efforts by establishing a China-Africa cooperation forum, called the Forum on China-Africa Cooperation (FOCAC). Concluded that the role of FOCAC is very important in fulfilling China for oil resources in Nigeria. Some of the collaborations carried out by China and Nigeria based on FOCAC resulted in good reciprocity for the two countries. The development relationship is increasingly seen until the framework of cooperation in free trade is made between China and Nigeria. Basically, many collaborative efforts carried out by China to Nigeria mean that China is easier to carry out oil exploration in Nigeria, but China also helps the recovery and growth of the Nigerian economy.
\end{abstract}

Keywords: economic management, energy, oil, FOCAC, cooperation

JEL Classification: F1

\section{Introduction}

China has begun to view requirements for economic growth in terms of national security (Heat, 2016). To develop the industrial sectors rapidly, which can lead to an increase in economic growth, then China made various efforts by means of management approach to countries with potentially large oil fields. This is due to the oil certainly requires much energy because it can affect the economic growth in China. China does not have enough oil fields to meet the needs of the country. Domestic oil production continues to decline coupled with high oil purchases by China to create disparities in the country. On the one hand, China does not want to pay more to explore the old oil wells in the country (Ventura, 2017). 
Table 1: Major Chinese imports (\$-billion), 2002-2004

\begin{tabular}{|c|c|c|c|c|}
\hline Commodity & 2002 & 2003 & 2004 & $\begin{array}{l}\text { Percentage } \\
\text { change } \\
(2004 / 03)\end{array}$ \\
\hline $\begin{array}{l}\text { Electrical machinery, equipment and parts; Sound recorders and } \\
\text { reproducers; Television recorders and reproducers, parts and } \\
\text { accessories }\end{array}$ & 26,4 & 41,9 & 61,4 & 46,8 \\
\hline Boilers, machinery, mechanical appliances and parts & 21,2 & 29,8 & 38,6 & 29,5 \\
\hline Crude oil & 12,8 & 19,8 & 33,9 & 71,1 \\
\hline Plastics & 17,4 & 21,0 & 28,1 & 33,4 \\
\hline Organic chemicals & 11,2 & 16,0 & 23,8 & 48,8 \\
\hline
\end{tabular}

Source: Global Trade Atlas, www.gtis.com/gta/ (accessed 5 March 2008); (Shelton and Paruk, 2008)

The high rates of development in China increasingly indicated the insufficiency of their own energy resources to maintain the positive dynamics of the growth of the national economy. In the absence of structural changes in the Chinese energy industry, exacerbation of the environmental problem is likely to reduce the inflow of foreign direct investment, on which the PRC economy is also mainly dependent (Kuznetsova and Kravchenko, 2019).

Africa is one of the China targets to gain compliance with the energy source of oil for the country. In 2000, China initiated the establishment of the Forum on China Africa Cooperation (FOCAC) together 53 African countries.

China's involvement in Africa has caused much debate. The increasing presence in Africa has drawn mixed reactions from the academic and media platforms. It has been argued that China is sapping Africa's manufacturing potential and also extracting Africa's resources without any significant benefits to Africa. Thus China is seen as a contributor to Africa's underdevelopment and deindustrialization. However, some have seen China as Africa's partner for development (Mlambo, Kushamba, Simawu, 2016).

China's political and economic activities in Africa are increasing at an exponential rate. Equally, they are attracting criticism, chiefly over Beijing's no-strings-attached stance on human rights and governance. It is clear that many African states that enjoy Chinese support not only trample on civil and political rights (as per Western ideas of human rights) but also subvert their citizens' economic and social rights (as per China's discourse on human rights) (Taylor, 2008).

FOCAC has proved over time to be an effective platform for China-Africa cooperation and aims to connect with the UN Agenda for sustainable development, the African Union's Agenda 2063 and individual economies development plans for the growth and revitalization of African economies in leaps and bounds with deeper human to human relationship, and sustained friendship (Achu, 2019).

Through FOCAC (Ventura, 2017), China has a big impact on countries in Africa, especially for economic growth in Africa. At the forum, China stated that it would provide debt relief in African countries amounted to ten billion yuan (1.2 million US \$). Besides China also abolishes import duties on trade goods to Africa. China also donated funds for infrastructure development (Ventura, 2017), Cooperation between China and Africa are also helping Africa achieve the UN millennium development goals and also generate prosperity and progress together (Chen, 2010).

Nigeria became one country that has a footprint of China in the country and the two countries had a lot of cooperation. Nigeria became the largest oil producer in the world to $12^{\text {th }}$ (Kabass, 2012) which can produce 2.4 million barrels of oil per day (Nigerian National Petroleum Corporation, 2018). Carrying oil sector contributing about $8.7 \%$ of the GDP of Nigeria and it is the largest export revenue in addition to the non-oil sector growing $0.5 \%$ (Rianti, 2018). In its development, China and Nigeria have reached a consensus to build a 
strategic partnership with mutual political trust, economic reciprocity and mutual assistance in international affairs. China attaches great importance to bilateral relations and will work with Nigeria to push the bilateral strategic partnership (Yan, 2006). Based on the description of the background of this, the authors will discuss the economic diplomacy conducted by China to Nigeria through the China-Africa cooperation forum in order to fulfil China's oil energy sources.

\section{Methodology}

Descriptive method of analysis is a research method that seeks to collect data, organize and interpret the data with the aim of description or explain these events and that there is at present in a systematic, factual, and accurate information on facts and properties of a particular population. The study was limited to operations express a problem or situation or event as in fact expresses the fact (fact-finding), which is then submitted to analyse the data or the phenomenon to look for solutions in linkages with the new strategy. With this descriptive method, the researchers wanted to figure out how the steps and efforts made by China to Nigeria meet the needs of the country's oil resources.

\section{Results}

China's focus of interest to Africa is more on resources, it means to the adequacy of energy, especially oil. We can see the results in Table 2 below.

Table 2: Chinese foreign direct investment in Africa by sector, in million USD from 1979-2000

\begin{tabular}{lll}
\hline Sector/industry & Number of projects & Value of the investments in million dollars USD \\
\hline Agriculture (Farming) & 22 & 48 \\
Extraction of the resources & 44 & 188 \\
Factory represented by: & 230 & 315 \\
1 Machines & 20 & 16 \\
2 Household electrical appliances & 36 & 25 \\
3 light Industry & 82 & 87 \\
4 Textiles & 58 & 102 \\
5 Other industrial products & 34 & 86 \\
Services & 200 & 125 \\
Other & 3 & 6 \\
Total & 499 & 681 \\
\hline
\end{tabular}

Source: UNCTAD in 2007; (Koumou and Manyi, 2016)

Table 2 showed that China focuses on energy by extraction of the resources. Epecially China focuses on oil which is to be seen in Figure 1. 
Figure 1: Oil production vs. consumption and natural gas production vs. consumption

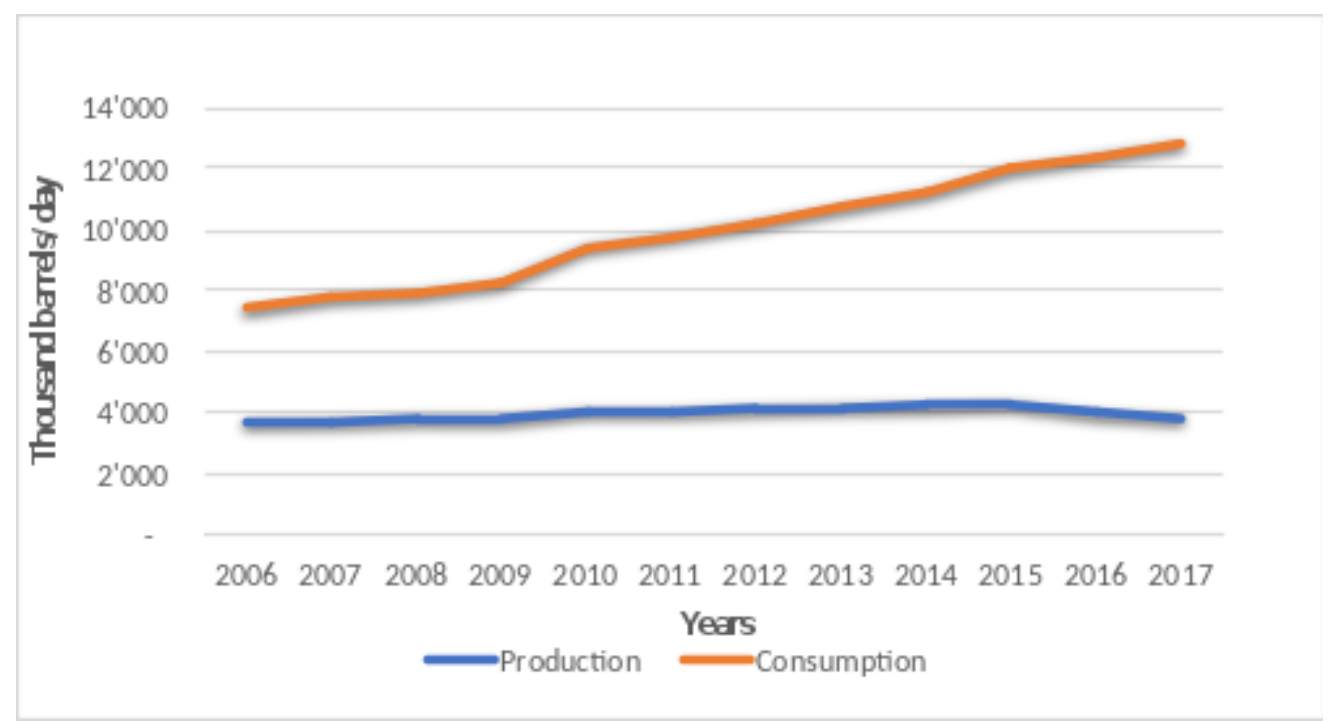

Source: The author, with data from the BP Statistical Review of World Energy (BP, 2018); (Vasquez, 2019)

To do their objectives China employs diplomacy or focus on economic diplomacy. Diplomacy is closely related to foreign policy because diplomacy is an implementation of foreign policy. Theory or system can be used to explain the link between diplomacy and foreign policy (Djelantik, 2008). Diplomacy means the management or economic diplomacy to reach economic goals. In general, economic diplomacy is the use of a country's efforts in using all elements of the existing economy, to international territories in order to meet national interests. Some understanding of economic diplomacy, according to experts, economic diplomacy proposed by Bayne and Woolcock (2003) is as follows:

"Economic diplomacy is a set of activities (both regarding methods and processes for international decision making) related to cross-border economic activities (export, import, investment, lending, aid, migration) pursued by state and non-state actors in the real world" (Bayne and Woolcock, 2003).

Besides the implementation of economic diplomacy can be classified into three forms, namely:

a. Trade: which preferably is in the form of exports and imports in order to meet the needs.

b. Investment: Investment is needed, especially by developing countries are still seeking economic growth. This foreign investment in outline form of capital.

c. Help: help can be food aid, medicines, clothing and can also be manual or mental empowerment (Bayne and Woolcock, 2003).

The concept of economic diplomacy is used to determine how the economic diplomacy is undertaken by China to Nigeria with through FOCAC, where economic diplomacy which is run by the second country will greatly help in achieving the success of the cooperation between the two countries.

\subsection{China's economic management to Nigeria}

There are three forms of implementation of economic management approach which trade, investment and aid, the third form of implementation that Chinese efforts to acquire energy resources of oil in Nigeria. The first is the trade, where since 2003 China has become the second largest country that exports to African countries to export products such as textiles, clothing, electronic equipment, and machines which then exports it has a very big market 
demand in Africa because the price is relatively low (Fransiska, 2015). According to the Economic and Commercial Counselor of the Chinese Embassy in Abuja, Zhao Linxiang expansion of exports to China will increase the economy of Nigeria and the balance of trade between the two countries. Because, basically, China and Nigeria have complementary advantages in many parts of which offer great potential for cooperation. China has the potential to become the largest consumer market in the world, where if China is increasing imports from other countries, it will help many countries in promoting the economic growth of these countries and can create jobs and also the balance of trade between countries (Salau, 2018). Nigeria's total imports increased from 5.3 billion US \$ in 1996 to 5.8 billion US \$ in 2000 and then to $\$ 17.7$ billion in 2005 . Nigeria imports almost all categories of products from China (EO Ogunkola, 2008). The volume of bilateral trade between China and Nigeria increased to nearly 14 billion US \$ with an increase of $29.7 \%$ over the previous year, adding that Nigeria continues to be the third largest trade partner of China in Africa (Sessou, 2016).

The second is in investments, the Chinese government has made reforms to deepen its investment in Nigeria. According to the Chinese Ambassador to Nigeria Zhou Pingjian, to further enhance bilateral relations with Nigeria, China expand investment in critical areas to improve the country's economic cooperation with Nigeria in the field of agriculture, manufacturing, industry capacity and investment, including infrastructure, energy, culture, exchange of people-to-people and other fields (Paulinus, 2018). Massive investments made in exploration and development projects in various countries by establishing three companies that handle the oil industry or the so-called National Oil Corporation (NOC), which is the China National Offshore Oil Corporation (CNOOC), the China National Petrochemical Corporation (Sinopec), The China National Petroleum Corporation (CNPC) (Naomi, 2010).

The third is an aid, China provided assistance to Nigeria with infrastructure development, due to poor infrastructure owned by Nigeria became one of the bottlenecks in the main economic-related industrial development and exports due to high transport costs reduce the competitiveness of the goods. With penunjangan good infrastructure, it will greatly help China in the distribution of the results of import and export of China and Nigeria. China made the manufacture of the railway line linking the capital of Nigeria, Abuja to Kaduna capital for three years. Dith the railway line can connect the federal capital Abuja with the commercial capital of Kaduna in which it allows the movement of goods and people more quickly between the two cities.

As the results of the 2015 meeting concentrate on the implementation of four main areas: industrialization; security and military cooperation; environmental protection; media cooperation; and educational exchanges. The Forum is an event that highlights the different areas of joint Chinese and African interests, but it may also be interpreted as a symbol of China's importance for Africa (Jiang, Li, etc., 2016).

China entered the offshore oil industry in countries such as Angola and Nigeria, ventured into conflict-ridden countries such as Chad, Sudan, Mauritania, Niger, and Equatorial Guinea, and looked for new exploration opportunities in Ethiopia, Kenya, Madagascar, and Uganda largely through joint ventures with national oil companies. China imports two-thirds of the oil it consumes, with Africa accounting for 22\% (1.4 million barrels per day), the second most important provider, after the Middle East. Oil imports from Angola constitute $47 \%$ of the African import market share in China, surpassing Saudi Arabia as China's largest source of crude oil imports in 2006. Africa is home to five of the top 30 oil-producing countries; Africa's proven oil reserves are listed at 130 billion barrels (at the end of 2012) (Powanga \& Giner, 2019). 
Nigeria as a dependent country on oil also opens for a multinational corporation to explore oil in the country. The Nigerian economy is heavily reliant on the oil sector. The International Monetary Fund estimates that the oil and gas sector in Nigeria accounts for over $95 \%$ of the foreign export earnings and about $65 \%$ of the Nigerian government revenue (IMF, 2013). The Oil and Gas Journal posits that Nigeria had an estimated 37.2 billion barrels of proven oil reserves as of January 2011 (Ekhator, 2014).

\section{Discussion}

Within the framework of FOCAC, the Government of China agreed to cooperate with African countries in the field of investment promotion relating to the formation and management of Special Economic Zone. After the completion of the forum, many Chinese private companies are competing to get the approval from the Ministry of Commerce of China (MOFCOM) in establishing a free zone in Africa Section. And at the end of 2006, MOFCOM finally approved a proposal to establish six special economic zones in Africa; including in Algeria, Egypt, Zambia, Nigeria, Mauritius and Ethiopia (Syakura and Rani, 2010). There are six countries, then Nigeria is one country in Africa that has the largest market consumers in Africa and has a population of about 150 million inhabitants. Its economy depends on the oil which has been responsible for $20 \%$ of Nigeria's GDP (183 billion US \$ in 2009) (Bijian, 2005).

Establishment of forums or organizations such as the highly visible role FOCAC used as a tool that is quite efficient in utilizing and exploring the potential of the African-owned energy supply. However, the utilization of energy sources is also a form of reciprocity for the assistance given by China to the socio-economic development of Africa. Because at the beginning of the establishment of the Forum on China Africa Cooperation (FOCAC) is a form of cooperation in exploring each potential possessed by the two countries, both in the political, economic, social, cultural and security. Various specific projects under the FOCAC has been created by China to Nigeria. Nigeria Partnership with China through FOCAC has resulted in the implementation of vital infrastructure projects across the country, worth more than $\$ 5$ billion in the last three years. The platform through FOCAC, China successfully built an increase in airport terminals, railway lines Lagos - Kano, hydroelectricity project Zungeru and fibre cables for the internet infrastructure of Nigeria (https://clubofmozambique.com/news/nigeria-reaps-5bn-benefit-from-partnership-withchina/,2019). With the existence of the forum also provided an opportunity for Nigeria to deepen the skills to transfer technology and skills of one of them by the shift in China's lowwage employment and labour-intensive open a new window for Nigeria (Chidiebere, 2018). The FOCAC also derived to national interest's provision both for China and Africa. The FOCAC Beijing Summit last September has given rise to a new boom in China-Africa exchanges and cooperation. The implementation of the summit outcomes is in full swing.

Firstly, High-level engagement and political mutual trust have reached a new high, with 17 state and party leaders from the Chinese side visiting 25 African countries and the AU Headquarters.

Secondly, the quality and efficiency related to the practical economic and trade cooperation have improved, with major projects supported by grants or concessional loans from China making steady progress. Last year, two-way trade again exceeded US\$200 billion, making China Africa's largest trading partner for the tenth straight year. 
Thirdly, the people-to-people and cultural exchanges are off to a new and bright start. The China-Africa Institute was inaugurated, the 8th edition of the China-Africa think-tank forum will be held in the next half year. The emergency aid provided to several African countries suffered from natural disasters reflects the profound friendship.

Fourthly, peace and security cooperation have achieved prominent results. China supports Africa to build up the peace-keeping capacity of its will, hurries at developing the implementation program of the China-Africa peace and security fund, with the aim at holding the first session of the China-Africa Peace and Security Forum this July in Beijing (Pingjian, 2019).

Table 3: Sources of China's oil imports (1999-2004) (10 000 tons)

\begin{tabular}{lllllllll}
\hline Region & $\mathbf{1 9 9 9}$ & $\mathbf{2 0 0 0}$ & $\mathbf{2 0 0 1}$ & $\mathbf{2 0 0 2}$ & $\mathbf{2 0 0 3}$ & $\mathbf{2 0 0 4}$ & $\begin{array}{l}\text { Growth } \\
\text { rate }(\mathbf{\%}) \\
\mathbf{2 0 0 3 - 0 4}\end{array}$ & $\begin{array}{l}\text { Rate } \\
(\mathbf{\%})\end{array}$ \\
\hline Mid-east & 1,690 & 3,765 & 3,386 & 3,439 & 4,636 & 5,578 & 20.3 & 45.4 \\
Africa & 724 & 1,694 & 1,354 & 1,579 & 2,218 & 3,530 & 59.1 & 28.7 \\
$\begin{array}{l}\text { Asia- } \\
\text { Pacific }\end{array}$ & 683 & 1,061 & 868 & 1,185 & 1,385 & 1,416 & 2.2 & 11.5 \\
W & 562 & 505 & 416 & 737 & 872 & 1,756 & 101 & 14.3 \\
$\begin{array}{l}\text { Hemisphere } \\
\text { Total }\end{array}$ & 3,661 & 7,026 & 6,025 & 6,941 & 9,112 & 12,282 & 100 & \\
\hline
\end{tabular}

Source: Paper presented by Wu Lei, professor of International Relations at Yunnan University, Kunmig, China, at the China-Arab Cooperation Forum (CACF) in Beijing on December 12-13, 2005 (Excecutive Research Associates (Pty) Ltd., 2008)

\section{Conclusion}

China's economic growth is very large, leading to the increased energy consumption of oil in the country. With huge oil demand, but with the limited availability of oil that is causing a great imbalance in terms of production and consumption. As a result, China should make efforts to meet the energy needs of the country's oil, to conduct economic diplomacy. The bilateral relationship between China and Nigeria in the aspect of increased trade that can be seen in 1996 China's total exports to Nigeria worth 5.8 billion US \$ and then in 2017 totalled 14 billion US $\$$ that because Nigeria became the third largest trading partner of China in Africa. The amount of the Nigerian population creates a huge market opportunity for Chinese goods, where most of China's export products such as textiles, clothing, electronic equipment, and machinery. China also requires products imported from Nigeria is oil, which since the cooperation of China and Nigeria China's main focus is to get the oil out of Nigeria's energy source.

China reform to deepen its investment in Nigeria. After the entry of Chinese investments through its companies mainly engaged in oil and gas fields by investing investment of 2.2 billion US \$ in Nigeria it strengthened the position of China in Nigeria, then the investment capital investment also for the control of oil fields in Nigeria. Then China to build a railway line that connects Abuja and Kaduna which are both a source of the domestic economy in Nigeria. Aid infrastructure development in Nigeria by China becomes one of supporting the implementation of import-export activities in China and Nigeria. Forum on China Africa Cooperation (FOCAC) as a bridge China to deepen its cooperation with Nigeria. Within the framework of FOCAC contains economic special zone, Nigeria included in one State which is the goal in establishing special economic zones in Africa even FOCAC has resulted in the implementation of vital infrastructure projects by China in Nigeria. 


\section{References}

Achu,O.D. (2019) FOCAC: An effective platform for collaboration. Crimson Publishers, Wings to the Research, 4(1). Available at: https://crimsonpublishers.com/mcda/pdf/MCDA.000580.pdf.

Bayne, N. \& Woolcock, S. (2003) The New Economic Diplomacy: Decision Making and Negotiation in International Economic Relations. Ashgate, London.

Chen, S. (2010) Cina bela perdagangan Afrika. Available at: https://www.bbc.com/indonesia/dunia/2010/12/101223_chinaafrica.

Chidiebere, E. E. (2018) Reshaping FOCAC China-Nigeria cooperation. Available at: http://www.chinadaily.com.cn/a/201808/29/WS5b863b75a310add14f3886f9.html.

Zheng, B. (2005) China's "Peaceful Rise" to great-power status. Foreign Affairs, 84(5), 18.

Yan, E. (2006) Chinese, Nigerian presidents agree to promote strategic partnership. Available at: http://www.newsgd.com/specials/huvisitfivenations06/huvisitfivenations06news/200604270017.html.

Ekhator, O.E. (2014) Corporate social responsibility and Chinese oil multinationals in the oil and gas industry of Nigeria: An appraisal.Cadernos de Estudos Affricanos, 28, 119-140.

EO Ogunkola, B.A.S \& Adewuyi, A. (2008) China-Nigeria Economic Relations. Ibadan: African Economic Research Consortium (AERC).

Excecutive Research Associetes. 2009. China in Africa A Strategic Overview. Confidential. ERA. Available at: Https://www.ide.go.jp/library/English/Data/Africa_file/Manualreport/pdf/china_all.pdf.

Fransisca, M. Kerjasama Ekonomi Republik Rakyat Tiongkok (RRT) - Nigeria Melalui Kerangka Forum on China - Africa Cooperation (FOCAC).

Heath, R.T. China's evolving approach to economic diplomacy, Asia Policy, 22, 157-192.

Jiang, F., Li, S., Ronning, H. \& Tjonnelan, E. (2016) The voice of China in Africa: Media, communication technologies and image-building. Chinese Journal of Communication, 9(1), 1-7.

Kabass, F.A. (2012) A Tale of Two superpowers: Nigeria and China Relations.

Komou, M., Fane, R. \& Manyi, W. (2016) Effects of Chinese foreign direct investment in Africa. Journal of Finance and Accounting, 4(3), 131-139.

Kuznetsova, V.N. \& Kravchenko, A.A. (2019) The Problems of China as a major consumer of energy resources. International Journal of Energy Economic and Policy, 10(1), 331-341.

Mlambo, C., Kushamba, A., Simawu, B. \& More, B. (2016). China-Africa relations: What lies beneath? Journal the Chinese Economy, 49(4), 257-276.

Nigeria Reaps $\$ 5$ BN Benefit from Partnership with China. Available at: https://clubofmozambique.com/news/nigeria-reaps-5bn-benefit-from-partnership-with-china/.

Nigerian National Potroleum Corporation. Chinese Oil Corporation taps into Nigerian resources. Available at: http://www.nnpcgroup.com/PublicRelations/NNPCinthenews/tabid/92/articleType/ArticleView/articleId/209 /Chinese-Oil-Corporation-taps-into-Nigerian-resources.aspx.

Paulinus, Aidoghie. 2018. China Renews Commitment to Deepen Investments in Nigeria. Available at: https://www.sunnewsonline.com/china-commitment-deepen-investments-nigeria/.

Powanga, L. \& Giner, I.R. (2019). China's contribution to the African power sector: Policy implications for African countries. Journal of Energy. 2019(7013594), 10.

Pingjian, Z. (2019) FOCAC: working toward even stronger China-Africa community with shared future (From Chinese Embassy in Nigeria) 2019/07/01. The Ministry of Foreign Affairs of People's Republic of China. Available at: Https://www.fmprc.gov.cn/mfa_eng/wjb_663304/zwjg_665342/zwbd_665378/t1677107.shtml.

Rianti, E. (2018). Produksi Minyak Pulih, Ekonomi Nigeria Rebound. Available at: http://market.bisnis.com/read/20180228/94/744204/produksi-minyak-pulih-ekonomi-nigeria-rebound. Accessed on October 28, 2018.

Salau, A. (2018). China Asks Nigeria to Expand Exports into Its Vast Market. Available at: https://www.dailytrust.com.ng/china-asks-nigeria-to-expand-exports-into-its-vast-market.html.

Sessou, E. (2016). Nigeria Maintains China's Top Trade Partner as Trade Volume Improves. Available at: https://www.vanguardngr.com/2018/07/nigeria-maintains-china-top-trade-partner-as-trade-volumeimproves/.

Shelton, G. \& Paruk, F. (2008). The forum on China-Africa cooperation a strategic opportunity. Monograph, 156.

Djelantik, S. (2008). Diplomasi Antara Teori dan Praktik. Graha Ilmu, 13.

Naomi, S.C. (2010). Journal Kepentingan Cina Menjalin Kerjasama Foreign Direct Investmen (FDI) dalam Bidang Energi (Minyak dan Gas) dengan Indonesia.

Syakura, A. \& Rani, F. (2006-2010). Kerjasama Cina Dan Nigeria Membuka Kawasan Lekki Free Trade Zone Di Nigeria Dalam Kerangka Special Economic Zone Of China (Tahun 2006-2010). 
China's economic policy to Nigeria in oil affairs Authors: Anton Minardi, Riani Fauziah Lestari

Taylor, I. (2008). Sino-African relations and the problem of human rights. African Affairs, 107(426), 63-87.

Vasquez, I.P. (2019). China's oil and gas footprint in Latin America and Africa.

Ventura, B. (2017). China Kalahkan as Sebagai Negara Imporir Minyak Terbesar. Available at: https://ekbis.sindonews.com/read/1196965/35/china-kalahkan-as-sebagai-negara-imporir-minyak-terbesar1492078903. 